\title{
MOTIVASI IBU HAMIL TW I DALAM MELAKUKAN PPIA (PENCEGAHAN PENULARAN HIV DARI IBU KE ANAK) DI WILAYAH KERJA PUSKESMAS SAWAN I
}

\author{
(Motivation Maternity in society health center in Doing MTCT (Mother to Child Transmissional) in \\ Puskesmas Sawan I)
}

\author{
Putu Monna Frisca Widiastini ${ }^{1}$, Desak Ketut Sugiartini ${ }^{2}$ \\ ${ }^{1}$ Program Studi Profesi Pendidikan Bidan \\ ${ }^{2}$ Program Studi D-III Kebidanan \\ Corespondence author: monnafrisca@yahoo.co.id \\ Current author: Sekolah Tinggi Ilmu Kesehatan Buleleng
}

\begin{abstract}
ABSTRAK
Pendahuluan : HIV (Human Immunodeficiency Virus) adalah virus yang menyerang sistem kekebalan tubuh manusia. Perkembangan infeksi yang disebabkan oleh HIV berlangsung progresif selama beberapa tahun sehingga menimbulkan berbagai tanda dan gejala penurunan kekebalan tubuh yang dikenal dengan istilah Aquired Immuno Deficiency Syndrome (AIDS). Penularan dapat terjadi melalui hubungan seksual yang tidak aman, penggunaan jarum suntik secara bergantian (tidak steril), tranfusi darah yang tercemar HIV, maupun penularan langsung dari ibu kepada janinnya Mother to Child Transmissional (MTCT). Tujuan penelitian ini adalah untuk mengetahui motivasi ibu hamil 0-12 minggu dalam melakukan PPIA di wilayah kerja Puskesmas Sawan I. Metode : Penelitian ini menggunakan metode penelitia deskriptif dengan menggunakan metode random sampling. Populasi dari penelitian ini adalah ibu hamil 0-12 minggu dengan jumlah 36 orang. Tekhnik pengumpulan data menggunakan kuesioner. Penelitian ini dilakukan pada bulan mei-juli 2020 di wilayah kerja puskesmas Sawan I. Hasil : Analisa data diketahui responden dengan motivasi tinggi yaitu 5 orang, motivasi sedang 11 orang dan rendah 20 orang. Kesimpulan : Dari penelitian ini ibu hamil yang terlibat dalam penelitian ini paling banyak memiliki motivasi dalam kategori rendah yaitu 20 orang dari 36 responden dalam mengikuti program PPIA di wilayah kerja Puskesmas Sawan I.
\end{abstract}

Kata Kunci : Motivasi Ibu Hamil, PPIA (Pencegahan Penularan HIV dari Ibu ke Anak)

\begin{abstract}
Preliminary : HIV (Human Immunodeficiency Virus) is a virus that attacks the human immune system. The development of infections caused by HIV do progressively during several years, it cause variety of signs and symptoms of immunedeficiency known as acquired Immuno Deficiency Syndrome (AIDS). Transmission can occur through unprotected sexual intercourse, sharing needles alternately (nonsterile), transfusion of blood contaminated with HIV, and direct transmission from mother to fetus of mother to child transmissional (MTCT). The purpose of this study is to determine the motivation of in first trisemester pregnant mother in doing PPIA in Sawan I society health center. Methods : this study uses descriptive empirically using random sampling method. The population of this study is pregnant mother of in first trisemester with the number of 36 people. Data collection technique using questionnaires. This study is conducted in Mei-July 2020 are the working area of Sawan I society health centre. Results : it showns that respondent with high motivation 5 people, moderate motivation are 11 and low motivation are 20. Conclusion : from this study is pregnant mother who are involved in this study most motivated in the low category, are 20 of the 36 responden in following PPIA programsin society of health centre are.
\end{abstract}

Keywords : Motivation Pregnancy, PPIA (prevention of HIV Transmission from Mother to Child) 


\section{PENDAHULUAN}

Human Immunodeficiency Virus (HIV) adalah virus yang menyerang sistem kekebalan tubuh manusia. Infeksi HIV dalam tubuh manusia tidak langsung menimbulkan gejala. Perkembangan infeksi yang disebabkan oleh HIV berlangsung progresif selama beberapa tahun sehingga menimbulkan berbagai tanda dan gejala penurunan kekebalan tubuh yang dikenal dengan istilah Aquired Immuno Deficiency Syndrome (AIDS). Mekanisme penularan dapat terjadi melalui hubungan seksual yang tidak aman, penggunaan jarum suntik secara bergantian (tidak steril), transfusi darah yang tercemar HIV, maupun penularan langsung dari ibu kepada janinnya Mother to Child Transmissional (MTCT) (Kemenkes, 2011).

Ditemukan di provinsi Bali pada tahun 1987. Hingga saat ini HIV-AIDS sudah menyebar di 386 kabupaten/kota di seluruh provinsi di Indonesia. Jumlah kasus AIDS menunjukkan kecendrungan meningkat secara lambat bahkan sejak tahun 2012 jumlah kasus AIDS mulai turun. Jumlah komulatif penderita HIV dari tahun 1987 sampai September 2014 sebanyak 150.296 orang, sedangkan total komulatif kasus AIDS sebanyak 55.799 orang. (Kemenkes RI, 2014). Penyebaran kasus HIV/AIDS di Bali saat ini lebih banyak ditularkan melalui hubungan seksual. Jumlah kematian akibat AIDS tahun 2014 sebanyak 54 orang; laki-laki 34 orang dan perempuan 20 orang. Angka kasus penderita HIV/AIDS atau ODHA yang mendapatkan pengobatan ARV tahun 2014 adalah 60,91\% lebih tinggi dari tahun 2013 sebesar 57,43\%. Hasil capaian Provinsi Bali pada tahun 2014 sudah melampaui baseline nasional di tahun 2014 sebesar 42\%, dan target sesuai Renstra Kemenkes di tahun 2015 sebesar 45\%. (Kemenkes, 2015).

Kehamilan merupakan salah satu periode penting dalam siklus reproduksi seorang wanita. Lama kehamilan yaitu 280 hari atau 40 pekan (minggu) atau 10 bulan (lunar months). Kehamilan dibagi atas tiga triwulan (trimester) : Kehamilan triwulan I antara minggu 0-12, kehamilan triwulan II antara minggu 12-28, dan kehamilan triwulan III antara minggu 28-40. Ibu hamil dapat memeriksakan kehamilannya pada dokter ahli kebidanan, dokter ahli lain, dokter umum, bidan, perawat bidan dan dukun terlatih. Dalam satu komunitas seperti di Indonesia, ada pusat-pusat kesehatan, yaitu PUSKESMAS dan KIA-nya. Ditempat tersebut, seorang ibu hamil dapat memeriksakan kehamilannya. (Mochtar, 2011).

Tujuan khusus dari penelitian ini yaitu mengidentifikasi jumlah ibu hamil Tw I di Puskesmas Sawan I pada bulan Maret-April tahun 2015 dan mengidentifikasi motivasi ibu hamil Tw I dalam melakukan PPIA (Pencegahan Penularan HIV dari Ibu ke Anak) di wilayah kerja Puskesmas Sawan I pada tahun 2016.

\section{METODE PENELITIAN}

Penelitian ini menggunakan teknik deskriptif adalah salah satu jenis penelitian yang tujuannya untuk menyajikan gambaran lengkap mengenai suatu fenomena atau kenyataan sosial, dengan jalan mendeskripsikan sejumlah variabel yang berkenaan dengan masalah dan unit yang diteliti antara fenomena yang diuji.

Teknik sampling adalah suatu proses seleksi yang digunakan dalam penelitian dari populasi yang ada, sehingga jumlah sampel akan melewati keseluruhan populasi yang ada (Notoatmodjo, 2010). Dalam penelitian ini pengambilan sampel dengan teknik probability yaitu menggunakan simpel random sampling, yaitu cara pengambilan sampel secara acak. Dikatakan simpel (sederhana) karena pengambilan anggotanya dari populasi yang dilakukan secara acak tanpa memperhatikan apa yang ada dalam populasi itu. Cara demikian dilakukan jika anggota populasi dianggap homogen. Pengambilan sampel secara sederhana dapat dilakukan dengan cara undian, memilih sampel dari daftar bilangan secara acak, dsb (Sugiyono, 2009).

Pengumpulan data diperoleh dari data primer, data primer diperoleh dari lembar kuesioner yang di lakukan peneliti kepada responden yang telah disiapkan dari peneliti. 
Dalam penelitan ini, alat pengumpulan data atau instrument penelitian yang digunakan adalah kuesioner yang berisi 20 pernyataan positif dan negatif pada ibu hamil di wilayah kerja Puskesmas Sawan I. Data yang sudah didapat akan diolah dengan langkah-langkah seperti pengecekan jawaban-jawaban dari pernyataan kuesioner yang telah di bagikan, melakukan pengkodean data yang terdiri dari beberapa kategori, memasukan data ke dalam komputer dan melakukan pengolahan data dengan menggunakan SPSS.

\section{HASIL}

Hasil penelitian mencakup karakteristik responden (usia, pendidikan, pekerjaan, dan paritas), tingkat motivasi responden dan tabulasi silang karakteristik.

\section{Karakteristik Responden}

Tabel 5.1 Karakteristik Demografi Responden

\begin{tabular}{|c|c|c|c|}
\hline No & Karakteristik & $\begin{array}{c}\text { Jumlah } \\
\text { (f) }\end{array}$ & Persentase (\%) \\
\hline \multirow[t]{4}{*}{1} & Usia & & \\
\hline & $<20$ tahun & 4 & 11,1 \\
\hline & $20-35$ tahun & 24 & 66,7 \\
\hline & $>35$ tahun & 8 & 22,2 \\
\hline \multirow[t]{5}{*}{2} & Pendidikan & & \\
\hline & SD & 9 & 25 \\
\hline & SMP & 10 & 27,8 \\
\hline & SMA & 15 & 41,7 \\
\hline & Perguruan Tinggi & 2 & 5,5 \\
\hline \multirow[t]{6}{*}{3} & Pekerjaan & & \\
\hline & IRT & 11 & 30,5 \\
\hline & PNS & 1 & 2,8 \\
\hline & Swasta & 10 & 27,8 \\
\hline & Buruh & 9 & 25 \\
\hline & Wiraswasta & 5 & 13,9 \\
\hline \multirow[t]{4}{*}{4} & Paritas & & \\
\hline & Primipara & 7 & 19,4 \\
\hline & Multipara & 19 & 52,8 \\
\hline & Grandemultipara & 10 & 27,8 \\
\hline
\end{tabular}

Berdasarkan tabel 5.1 diatas dapat dijelaskan bahwa dari 36 responden, sebagian besar berada pada kategori usia 20-35 tahun sebanyak 24 responden $(66,7 \%)$, berpendidikan SMA sebanyak 15 responden $(41,7 \%)$, dari IRT sebanyak 11 responden $(30,5 \%)$, dan dari golongan multipara (pernah melahirkan lebih dari 1 kali) sebanyak 19 responden $(52,8 \%)$.

\section{Tingkat Motivasi Responden}

Tabel 5.2 Motivasi Ibu Hamil Tw I dalam Melakukan PPIA

\begin{tabular}{cccc}
\hline No & Kriteria & Jumlah (f) & Presentase (\%) \\
\hline 1 & Tinggi & 5 & 13,9 \\
\hline
\end{tabular}

\begin{tabular}{lccc}
\hline 2 & Sedang & 11 & 30,6 \\
\hline 3 & Rendah & 20 & 55,6 \\
\hline & Jumlah & $\mathbf{3 6}$ & $\mathbf{1 0 0}$ \\
\hline
\end{tabular}

Tabel 5.2 diatas menunjukkan dari 36 responden sebagian besar memiliki motivasi rendah sebanyak 20 responden $(55,6 \%)$.

\section{Tabulasi Silang Hasil Penelitian}

Tabel 5.3 Tabulasi Silang Berdasarkan Motivasi Responden dengan Usia

\begin{tabular}{lllllllll}
\hline & \multicolumn{6}{c}{ Usia } & \multicolumn{2}{c}{} \\
\cline { 2 - 7 } Motivasi & \multicolumn{2}{c}{$\begin{array}{c}\mathbf{2 0 - 3 5} \\
\text { Tahun }\end{array}$} & \multicolumn{2}{c}{$\begin{array}{c}>\mathbf{3 5} \\
\text { Tahun }\end{array}$} & \multirow{2}{*}{ Total } \\
\cline { 2 - 8 } & $\mathbf{F}$ & $\mathbf{\%}$ & $\mathbf{F}$ & $\mathbf{\%}$ & $\mathbf{F}$ & $\mathbf{\%}$ & $\mathbf{f}$ & $\mathbf{\%}$ \\
\hline Tinggi & 2 & 5,6 & 2 & 5,6 & 1 & 2,8 & 5 & 13,9 \\
\hline Sedang & 2 & 5,6 & 6 & 16,7 & 3 & 8,3 & 11 & 30,6 \\
\hline Rendah & 0 & 0 & 16 & 44,4 & 4 & 11,1 & 20 & 55,6 \\
\hline Total & $\mathbf{4}$ & $\mathbf{1 1 , 1}$ & $\mathbf{2 4}$ & $\mathbf{6 6 , 7}$ & $\mathbf{8}$ & $\mathbf{2 2 . 2}$ & $\mathbf{3 6}$ & $\mathbf{1 0 0}$ \\
\hline
\end{tabular}

Tabel 5.3 diatas menunjukkan responden dari kategori usia $<20$ tahun dengan jumlah 4 responden $(11,1 \%)$, sebagian besar dengan motivasi tinggi dan sedang masing-masing sebanyak 2 responden $(5,6 \%)$. Kategori usia 20-35 tahun yang berjumlah 24 responden $(66,7 \%)$, sebagian besar memiliki motivasi rendah sebanyak 16 responden $(44,4 \%)$. Kategori usia $>35$ tahun dengan jumlah 8 responden $(22,2 \%)$, sebagian besar dengan motivasi rendah sebanyak 4 responden $(11,1 \%)$.

Tabel 5.4 Tabulasi Silang berdasarkan Motivasi dengan Pendidikan Responden

\begin{tabular}{|c|c|c|c|c|c|c|c|c|c|c|}
\hline \multirow{3}{*}{ Motivasi } & \multicolumn{6}{|c|}{ Pendidikan } & \multirow{2}{*}{\multicolumn{2}{|c|}{$\begin{array}{l}\text { Perguru } \\
\text { an tinggi }\end{array}$}} & \multirow{2}{*}{\multicolumn{2}{|c|}{ Total }} \\
\hline & \multicolumn{2}{|c|}{ SD } & \multicolumn{2}{|c|}{ SMP } & \multicolumn{2}{|c|}{ SMA } & & & & \\
\hline & $\bar{f}$ & $\%$ & $\mathbf{F}$ & $\%$ & $\mathbf{F}$ & $\%$ & $\mathbf{F}$ & $\%$ & $\mathbf{F}$ & $\%$ \\
\hline Tinggi & 1 & 2,8 & 3 & 8,3 & 1 & 2,8 & 0 & 0 & 5 & 13,9 \\
\hline Sedang & 2 & 5,6 & 2 & 5,6 & 7 & 19,4 & 0 & 0 & 11 & 30,6 \\
\hline Rendah & 6 & 16,7 & 5 & 13,9 & 7 & 19,4 & 2 & 5,6 & 20 & 55,6 \\
\hline Total & 9 & 25,0 & 10 & 27,8 & 15 & 41,7 & 2 & 5,6 & 36 & 100 \\
\hline
\end{tabular}

Tabel 5.4 diatas menunjukkan responden yang berpendidikan SD dengan jumlah 9 responden $(25.0 \%)$, sebagian besar memiliki motivasi rendah sebanyak 6 responden $(16,7 \%)$. Responden dari pendidikan SMP dengan jumlah 10 responden $(27,8 \%)$, sebagian besar memiliki motivasi rendah sebanyak 5 responden $(13,9 \%)$. Responden dari pendidikan SMA berjumlah 15 responden $(41,7 \%)$, sebagian besar memiliki motivasi sedang dan rendah yaitu sebanyak 7 responden $(19,4 \%)$, dan dari kategori pendidikan perguruan tinggi berjumlah 2 responden $(5,6)$, sebagian besar memiliki motivasi rendah yaitu sebanyak 2 responden $(5,6)$.

Tabel 5.5 Tabulasi Silang antara Pekerjaan dengan Motivasi Responden

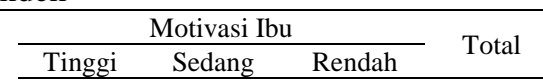




\begin{tabular}{cccccccccc}
\cline { 2 - 10 } & & $\mathbf{F}$ & $\mathbf{\%}$ & $\mathbf{F}$ & $\mathbf{\%}$ & $\mathbf{F}$ & $\mathbf{\%}$ & $\mathbf{f}$ & $\mathbf{\%}$ \\
\hline & IRT & 1 & 2,8 & 3 & 8,3 & 7 & 19,4 & 11 & 30,6 \\
\cline { 2 - 10 } $\begin{array}{c}\text { Peke } \\
\text { rjaan } \\
\text { Ibu }\end{array}$ & PNS & 1 & 2,8 & 0 & 0 & 0 & 0 & 1 & 2,8 \\
\cline { 2 - 9 } & Swasta & 0 & 0 & 5 & 13,9 & 5 & 13,9 & 10 & 27,8 \\
\cline { 2 - 9 } & $\begin{array}{c}\text { Buruh } \\
\text { asta }\end{array}$ & 2 & 5,6 & 3 & 8,3 & 4 & 11,1 & 9 & 25,0 \\
\hline $\begin{array}{c}\text { Tota } \\
1\end{array}$ & & 5 & $\begin{array}{c}13,8 \\
9\end{array}$ & 11 & 30,6 & 20 & 55,6 & 36 & 100 \\
\hline
\end{tabular}

Tabel 5.5 diatas menunjukkan responden yang sebagai IRT dengan jumlah 11 responden $(30,6 \%)$, sebagian besar memiliki motivasi rendah yaitu 7 responden $(19,4 \%)$. Responden yang bekerja sebagai PNS dengan jumlah 1 responden $(2,8 \%)$ memiliki motivasi tinggi. Responden yang bekerja sebagai Swasta dengan jumlah 10 responden $(27,8 \%)$, sebagian besar memiliki motivasi sedang dan rendah yaitu 5 responden $(13,9 \%)$. Responden yang bekerja sebagai Buruh dengan jumlah 9 responden $(25,0 \%)$ sebagian besar memiliki motivasi rendah yaitu 4 responden $(11,1 \%)$. Responden yang bekerja sebagai Wiraswasta dengan jumlah 5 responden $(13,9 \%)$ sebagian besar memiliki motivasi rendah yaitu 4 responden $(11,1 \%)$.

Tabel 5.6 Tabulasi Silang antara Paritas dengan Motivasi Responden

\begin{tabular}{|c|c|c|c|c|c|c|c|c|}
\hline \multirow{3}{*}{ Motivasi } & \multicolumn{6}{|c|}{ Paritas } & \multirow{2}{*}{\multicolumn{2}{|c|}{ Total }} \\
\hline & \multicolumn{2}{|c|}{ Primi-para } & \multicolumn{2}{|c|}{ Multi-para } & \multicolumn{2}{|c|}{$\begin{array}{c}\text { Grande } \\
\text { Multi- } \\
\text { para }\end{array}$} & & \\
\hline & $\mathbf{f}$ & $\%$ & $\mathbf{F}$ & $\%$ & $\mathbf{F}$ & $\%$ & f & $\%$ \\
\hline$\overline{\text { Tinggi }}$ & 0 & 0 & 4 & 11,1 & 1 & 2,8 & 5 & 13,9 \\
\hline Sedang & 3 & 8,3 & 4 & 11,1 & 4 & 11,1 & 11 & 30,6 \\
\hline Rendah & 4 & 11,1 & 11 & 30,6 & 5 & 13,9 & 20 & 55,6 \\
\hline Total & 7 & 19,4 & 19 & 52,8 & 10 & 27,8 & 36 & 100 \\
\hline
\end{tabular}

Tabel 5.6 diatas menunjukkan responden primipara yang berjumlah 7 responden $(19,4 \%)$, sebagian besar memiliki motivasi rendah sebanyak 4 responden $(11,1 \%)$. Responden multipara yang berjumlah 19 responden $(52,8 \%)$, sebagian besar memiliki motivasi rendah sebanyak 11 responden (30,6\%). Kategori grandemultipara berjumlah 10 responden $(27,8 \%)$ sebagian besar memiliki motivasi rendah sebanyak 5 responden $(13,9 \%)$.

\section{PEMBAHASAN}

Berdasarkan hasil penelitian dari 36 responden yang diteliti menunjukkan bahwa sebagian besar responden memiliki kategori motivasi rendah yaitu sebanyak 20 responden $(55,5 \%)$, motivasi sedang sebanyak 11 responden
$(30,6 \%)$, dan yang motivasi tinggi sebanyak 5 responden $(13,9 \%)$. Peneliti berpendapat bahwa tingkat motivasi ibu hamil dalam melakukan PPIA (Pencegahan Penularan HIV dari Ibu ke Anak) sangat dipengaruhi oleh beberapa faktor, diantaranya usia, pendidikan, pekerjaan, dan paritas. Menurut Widayatun (2009), menyebutkan bahwa semakin seseorang menjadi dewasa maka pengalaman dan pengetahuan akan semakin bertambah serta memungkinkan kemampuan dalam menganalisa sesuatu akan bertambah pula karena umur merupakan tingkat penilaian seseorang dianggap dewasa dan matang dalam berpikir.

Diketahui dari usia responden, dari 36 responden yang diteliti berdasarkan usia menunjukkan bahwa responden yang berusia $<20$ tahun sebanyak $11,1 \%$, yang berusia 20-35 tahun sebanyak $66,7 \%$, dan yang berusia $>35$ tahun sebanyak $22,2 \%$, dengan tingkat motivasi yang sebagian besar rendah berasal dari golongan usia 20-35 tahun yaitu sebanyak 44,4\%. Peneliti berpendapat, bahwa semakin bertambahnya usia akan semakin berkembang pula daya tangkap dan pola pikirnya dalam penerimaan informasi.

Berdasarkan jenjang pendidikan, dari 36 responden yang diteliti dari jenjang pendidikan SD sebesar 25,0\%, dari jenjang pendidikan SMP $27,8 \%$, dari jenjang pendidikan SMA sebanyak $41,7 \%$, dan dari jenjang pendidikan perguruan tinggi 5,6\%, dengan hasil tingkat motivasi yang diketahui sebagian besar dari jenjang pendidikan SMA yaitu 41,7\%. Menurut peneliti, tingkat pendidikan ibu hamil akan mempengaruhi tingkat motivasi ibu hamil tersebut dalam melakukan PPIA (Pencegahan Penularan HIV dari Ibu ke Anak) karena pada umumnya tingkat pengetahuan dari seseorang juga akan sangat mempengaruhi motivasi dalam melakukan program PPIA (Pencegahan Penularan HIV dari Ibu ke Anak), karena semakin tinggi pendidikan seseorang semakin baik pula tingkat pengetahuan seseorang. Pendidikan adalah suatu usaha untuk mengembangkan kepribadian serta kemampuan baik di dalam maupun di luar sekolah dan berlangsung seumur hidup. Pendidikan mempengaruhi proses belajar, semakin tinggi pendidikan seseorang, maka semakin mudah orang tersebut dalam menerima informasi.

Jika dilihat dari pekerjaan 36 responden yang diteliti, terdapat $30,6 \%$ responden yang bekerja sebagai IRT, sebanyak $2,8 \%$ responden yang bekerja sebagai PNS, sebanyak 27,8\% 
responden yang bekerja sebagai Swasta, sebanyak $25,0 \%$ responden yang bekerja sebagai buruh dan sebanyak $13,9 \%$ responden yang bekerja sebagai wiraswasta. Dengan tingkat pengetahuan yang kurang, diketahui dari kelompok responden yang bekerja sebagai IRT sebesar 30,6\%. Menurut peneliti motivasi ibu hamil dalam melakukan PPIA (Pencegahan Penularan HIV dari Ibu ke Anak) dipengaruhi juga oleh pekerjaan, ibu-ibu yang bekerja otomatis akan memiliki motivasi dalam melakukan PPIA (Pencegahan Penularan HIV dari Ibu ke Anak) pengetahuan baru yang terus berkembang di lingkungan kerjanya

Berdasarkan paritas 36 responden yang telah diteliti, ditemukan $19,4 \%$ responden yang termasuk primipara, $52,8 \%$ responden yang termasuk multipara, $27,8 \%$ responden yang termasuk grande multipara, dengan hasil tingkat motivasi yang kurang diketahui dari kategori multipara yaitu sebesar 52,8\%. Menurut peneliti, semakin banyak paritas termasuk pengalaman seorang ibu, semakin tinggi pula tingkat pengetahuan ibu tersebut dalam pengambilan keputusan.

\section{SIMPULAN DAN SARAN}

\section{Simpulan}

Berdasarkan hasil penelitian mengenai Motivasi Ibu Hamil Dalam Melakukan PPIA (Pencegahan Penularan HIV dari Ibu ke Anak) di wilayah kerja Puskesmas Sawan I, kesimpulan yang bisa saya ambil yaitu berdasarkan hasil penelitian yang dilakukan bahwa motivasi ibu hamil dalam melakukan PPIA (Pencegahan Penularan HIV dari Ibu ke Anak) di wilayah kerja Puskesmas Sawan I sebagian besar tergolong rendah yaitu sebanyak 20 responden $(55,5 \%)$ dari 36 responden, sebagian sedang dalam kategori sedang yaitu sebanyak 11 responden $(30,5 \%)$ dan sebagian kecil dalam kategori motivasi tinggi yaitu sebanyak 5 responden (14\%). Dalam hal ini motivasi juga dapat dipengaruhi oleh yaitu dari segi umur, tingkat pendidikan, jenis pekerjaan dan paritastau jumlah anak, selain dari faktor intrinsik seperti fisik, mental, kematangan usia pengelolaan diri dan tingkat pendidikan, faktor ekstrinsik seperti lingkungan, agama dan kepercayaan serta penguatan/kekuatan.

\section{Saran}

Hasil penelitian ini diharapkan dapat dikembangkan lebih lanjut dan tidak terbatas hanya pada identifikasi motivasi saja, namun masih banyak faktor lain yang perlu diteliti agar hasil yang dicapai dapat lebih sempurna.

\section{DAFTAR PUSTAKA}

Uno, Hamzah B. 2012. Teori Motivasi dan pengukurannya. Jakarta : Bumi Aksara

Sugiyono. (2012). Memahami Penelitian Kualitatif. Bandung : ALFABETA.

Arikunto, S. (2006). "prosedur Penelitian Suatu Pendekatan Praktik". Jakarta : PT. RINEKA CIPTA

Notoatmodjo, S. 2007. Pendidikan dan Perilaku Kesehatan. Jakarta: PT. Rineka Cipta

Mochtar, Rustam. 2011. Sinopsis Obstetri. Jakarta : EGC

Prawirohardjo, Sarwono. 2009. Ilmu Kebidanan . Jakarta : PT Bina Pustaka Sarwono Prawirohardjo, 2009

Arikunto, Suharsimi. 2010. Prosedur Penelitian Suatu Pendekatan Praktik. Jakarta : Rineka Cipta

Manuaba, Candranita. 2010. Ilmu Kebidanan Penyakit Kandungan dan KB. Jakarta : EGC

Prawirohardjo, Sarwono. 2010. IImu Kebidanan . Jakarta : PT. Bina Pustaka Sarwono Prawirohardjo.

Hidayat, Alimunl, A. 2007. Metode Penelitian Kebidanan Dan Tehnik Analisa Data. Salemba Jakarta : Medika

Jannah, Nurul. 2012. Buku Ajar Asuhan Kebidanan:Kehamilan. Yogyakarta : CV Andi OF SET

Sulistyawati, Ari. 2009.Asuhan Kebidanan Pada Masa Kehamilan. Yogyakarta: Salemba Medika

Pedoman nasional pencegahan penularan HIV dari ibu ke anak. Jakarta : Kementerian Kesehatan RI. 2011 
Jurnal Kesehatan MIDWINERSLION

Vol. 5, No. 2, September 2020

http://ejournal.stikesbuleleng.ac.id/index.php/Midwinerslion | 424 